\title{
ETNOMATEMATIKA : Matematika dalam Kehidupan Petani di Kabupaten Karawang
}

\author{
Indrie Noor Aini \\ Pendidikan Matematika FKIP Universitas Singaperbangsa Karawang \\ indrienooraini@gmail.com
}

Dikirim: 26 Januari 2018; Diterima: 26 Februari 2018; Dipublikasikan: 31 Maret 2018

\begin{abstract}
ABSTRAK
Penelitian ini bertujuan untuk menelaah istilah atau simbol matematika yang digunakan oleh petani di Kabupaten Karawang. Dalam kehidupan sehari-hari mereka telah menggunakan konsep matematika yaitu diantaranya bangun datar. Matematika yang lahir dari budaya dinamakan etnomatematika. Metodologi yang digunakan adalah metode penelitian deskriptif eksploratif dengan subjek penelitiannya adalah petani di salah satu desa di Kabupaten Karawang. Fenomena yang dijelaskan dalam penelitian ini adalah etnomatematika dalam kehidupan petani di Kabupaten Karawang. Hasil penelitian ini adalah bahwa petani di Karawang menggunakan matematika dalam kegiatan sehari-hari untuk menentukan luas sawah, menghitung luas sawah, mengukur panjang dan lebar sawah dan menentukan jarak antara benih padi. Hal ini menggambarkan bahwa memiliki kemampuan etnomatematika yang baik dan perlu disosialisasikan, digunakan dan dipelihara secara khusus oleh pendidik formal.
\end{abstract}

Kata Kunci : Etnomatematika, petani di Kabupaten Karawang 


\section{PENDAHULUAN}

Etnomatematika merupakan istilah yang mengaitkan budaya dengan konsep matematika yang dikemukakan oleh D'Ambrosio (1985) seorang matematikawan Brazil mendefinisikan: "Ethnomathematics is the way different cultural groups mathematise (count, measure, relate, classify, and infer)".

Etnomatematika tumbuh dan berkembang dari budaya, maka masyarakat sering tidak menyadari mereka telah menggunakan matematika. Dengan demikian, perlu ditunjukkan bahwa dalam kesehariannya masyarakat tidak asing lagi dengan konteks matematika. Berdasarkan hasil wawancara dengan Kepala Desa di salah satu daerah di Kabupaten Karawang, menyebutkan bahwa Kabupaten Karawang sebagian besar bentuk tanahnya merupakan dataran yang relatif rata. Hanya sebagian kecil wilayah yang bergelombang dan berbukit-bukit dengan ketinggian antara 0 1200 m. Kabupaten Karawang juga dilalui oleh aliran sungai yang melandai ke utara, sehingga sangat mudah untuk pengairan sawah dan akibatnya sawah di Kabupaten Karawang tumbuh subur.

Selain sungai, terdapat 3 buah saluran irigasi yang besar yang dimanfaatkan untuk pengairan sawah, tambak dan pembangkit tenaga listrik. Sehingga pada tahun 1990 an Kabupaten Karawang dijuluki lumbung padi Jawa Barat. Banyak sawah terhampar di beberapa daerah di Kabupaten Karawang. Sehingga sebagian besar masyarakatnya adalah petani.

Secara tradisional proses jual beli sawah dan hasil panennya dilakukan dengan sangat sederhana. Dari mulai pengukuran untuk penentuan luas sawah sampai pada ukuran tanam bibit padinya. Seperti hasil wawancara dengan petani, cara mengukur panjang dan lebar sawah adalah menggunakan bambu yang ukurannya telah disepakati disebut kemplang.

Selanjutnya menentukan jarak tanam benih padi juga menggunakan tali yang dibentangkan, disebut caplak yang akan membentuk kotak-kotak. Dengan memperhatikan pola yang ada secara tidak sadar masyarakat telah menggunakan konsep bangun datar. Apabila pembelajaran matematika dikaitkan dengan budaya yang tumbuh dan berkembang dalam masyarakat maka peserta didik akan merasa memiliki matematika, sehingga ia akan tertarik untuk mempelajarinya. Tujuan dari penelitian ini adalah untuk menelaah istilah atau symbol matematika yang digunakan oleh petani di Kabupaten Karawang.

Sebagaimana dikemukakan oleh Barton bahwa "Ethnomathematics is a field of study which examines the way people from other cultures understand, articulate and use concepts and practices which are from their culture and which the researcher describes as mathematical" (Barton, 2016). Kajian etnomatematika yang begitu luas, menyebabkan etnomatematika dianggap sebagai salah satu pusat pemikiran untuk memahami matematika. Karena matematika merupakan abstraksi pikiran manusia yang digunakan sebagai alat untuk pemecahan masalah. Sehingga menimbulkan pemikiran dan gagasan bahwa etnomatematika seharusnya mempunyai peran dan pengaruh yang besar dalam masyarakat dan pendidikan, khususnya dalam pendidikan matematika. Peran dan pengaruh tersebut sebenarnya sangat nyata, tinggal seberapa besar kita melestarikannya dan mengaitkannya dalam proses pembelajaran, sehingga siswa dapat dengan mudah memahami matematika jika konsep yang diajarkannya sesuai dengan yang mereka alami dalam kehidupan sehari-hari.

Oleh karena itu, jika kita bisa menciptakan sebuah kondisi di mana pendekatan etnomatematika dijadikan pendekatan dalam proses pembelajaran matematika, maka diharapkan dapat membuat pembelajaran yang relevan dan penuh makna bagi siswa.

Tujuan dari penelitian ini adalah untuk menelaah istilah atau simbol matematika yang digunakan oleh petani di Kabupaten Karawang, sehingga hasil dari penelitian ini bisa diaplikasikan dalam kegiatan pembelajaran. 


\section{METODE PENELITIAN}

Metodologi yang digunakan dalam penelitian ini adalah metode penelitian deskriptif. Sugiyono (2017) menyatakan bahwa metode deskriptif adalah suatu metode yang digunakan untuk menggambarkan atau menganalisis suatu hasil penelitian tetapi tidak digunakan untuk membuat kesimpulan yang lebih luas. Penelitian deskriptif melakukan analisis hanya sampai taraf deskriptif yaitu menganalisis dan menyajikan data secara sistematik, sehingga dapat lebih mudah dipahami dan disimpulkan.

Penelitian deskriptif eksploratif bertujuan untuk menggambarkan keadaan suatu fenomena, dalam penelitian ini tidak dimaksudkan untuk menguji hipotesis tertentu tetapi hanya menggambarkan apa adanya suatu variable, gejala atau keadaan (Arikunto, 2002). Fenomena yang dijelaskan dalam penelitian ini adalah etnomatematika dalam kehidupan petani di Kabupaten Karawang.

Prosedur dalam pelaksanaan penelitian ini adalah menelaah gejala-gejala atau dalam hal ini kebiasaan yang ada pada kehidupan Petani di Kabupaten Karawang. Penelitian ini berlokasi di salah satu Desa di Kabupaten Karawang.

\section{HASIL DAN PEMBAHASAN}

Hasil penelitian menunjukkan bahwa etnomatematika masih banyak digunakan oleh masyarakat Kabupaten Karawang terutama oleh para petani padi, berbagai perhitungan dan penggambaran etnomatematika masih banyak digunakan antara lain simbol untuk menentukan luas, menghitung luas sawah, mengukur panjang dan lebar sawah, menentukan jarak antara benih padi, menghitung banyaknya benih yang diperlukan dan menghitung banyaknya pupuk yang digunakan dalam satu kali musim panen. Masih ada Petani di Kabupaten Karawang yang dengan sederhana melestarukan budaya mereka. Mereka tidak tergerus oleh kemajuan dan perkembangan zaman.

Secara rinci beberapa jenis etnomatematika yang masih banyak digunakan oleh petani di Kabupaten Karawang dijelaskan sebagai berikut:

1. Simbol untuk menentukan luas diantaranya:

Petani di Kabupaten Karawang memiliki beberapa tolak ukur untuk mengukur luas sawah,

a. Tumbak, istilah tumbak digunakan untuk menggambarkan sebidang tanah yang berukuran sama dengan 14 meter persegi. Istilah lain dari tumbak adala Bata.

b. Bau, istilah tumbak digunakan untuk menggambarkan sebidang tanah yang berukuran sama dengan 5.000 meter persegi.

2. Menghitung Luas Sawah

Dalam menghitung luas sawah, mereka menggunakan rumus luas persegi panjang atau persegi yang seperti pada konsep matematika yang diajarkan di sekolah. Tetapi jika sawahnya berbentung sunsang, artinya keempat ukurannya tidak sama, maka dengan sangat sederhana cara menghitung luasnya adalah:

Untuk mendapatkan ukuran panjang, $(a+b): 2$. Untuk mendapatkan ukuran lebar $(c+d): 2$. Setelah didapat ukuran panjang dan lebarnya, kemudian dicari luassnya menggunakan rumus persegi panjang. Cara tersebut disepakati termasuk untuk cara jual beli tanah. Pengukuran ini jika didekati dari konsep matematika adalah menggunakan garis selidik pada konsep segitiga. 


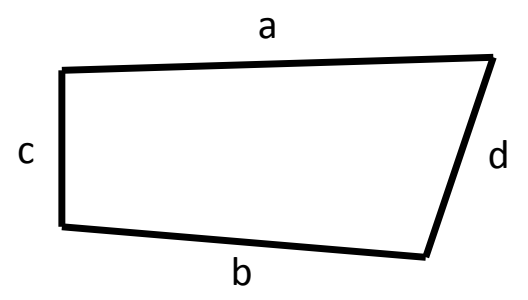

\section{Gambar 1. Ilustrasi Gambar Sawah}

3. Mengukur panjang dan lebar sawah

Pada umumnya, proses pengukuran menggunakan meteran, namun di Karawang ada kebiasaan yang dilakukan petani dalam mengukur sawahnya yaitu dengan menggunakan kemplang. Kemplang adalah bambu yang berukuran 1,5 - 2 meter. Jadi mereka mengukur dari satu titik pojok sawah ke titik pojok lain.

4. Menentukan jarak antar benih

Untuk menentukan jarak antar benih digunakan caplak. Caplak berbentuk segiempat, untuk mendapatkan jarak yang sama antar benih, maka petani membuat garisan-garisan pada sebidang sawah dengan menggunakan caplak tersebut. Sehingga nantinya terdapat banyak persegi yang disetiap titik pojoknya ditanami benih. Ukuran caplak ada yang $20 \times 20 \mathrm{~cm}$ ada juga yang berukuran $20 \times 25 \mathrm{~cm}$.

\section{KESIMPULAN}

Dalam budaya di Karawang yang sudah tersisih oleh dunia industri, masih ada petani yang menggunakan matematika dalam kegiatan sehari-hari untuk menentukan luas sawah, menghitung luas sawah, mengukur panjang dan lebar sawah dan menentukan jarak antara benih padi. Hal ini menggambarkan bahwa petani di Karawang memiliki kemampuan etnomatematika yang baik dan perlu disosialisasikan, digunakan dan dipelihara secara khusus oleh pendidik formal.

Selain memberi gambaran umum kepada generasi muda di Karawang tentang budaya yang nyaris tergerus oleh zaman, penelitian ini juga diharapkan bisa memberikan inspirasi dan motivasi bagi pemerintah untuk melestarikannya budaya melalui etnomatematika pada program pendidikan matematika yang realistis.

\section{REKOMENDASI}

Berdasarkan hasil temuan yang diperoleh pada penelitian ini, rekomendasi yang dapat disampaikan sebagai berikut:

1. Etnomatematika bisa dikaji lebih banyak dan lebih dalam di Kabupaten Karawang

2. Hasil dari penelitian ini diharapkan bisa menjadi bahan ajar yang bisa diaplikasikan dalam proses pembelajaran untuk siswa sekolah menengah pertama di kabupaten Karawang

\section{UCAPAN TERIMA KASIH}

Tiada kata yang lebih indah selain puji sukur yang tiada terukur penulis panjatkan kehadirat Allah SWT. atas rahmat dan karunia-Nya, penulis dapat menyelesaikan penelitian ini. Penulis menyadari sepenuhnya bahwa penelitian ini tidak akan terealisasikan dengan baik dan lancar tanpa adanya bantuan dari berbagai pihak baik bantuan berupa materi, bimbingan maupun dorongan 
semangat. Untuk itu pada kesempatan ini penulis menyampaikan ucapan terima kasih dan penghargaan yang setulus-tulusnya kepada:

1. Prof. Dr. H. Zulkardi, M. I. Komp., M. Sc. selaku ketua promotor yang senantiasa memberikan kemudahan dalam menyelesaikan penelitian ini.

2. Prof. Dr. Ratu IIma Indra Putri, M.Si. selaku anggota promotor yang telah membimbing.

3. Prof. Turmudi, M.Ed., M.Sc., Ph.D. selaku anggota promotor yang selalu memberikan bimbingan dan arahan dalam penelitian ini.

Segala bantuan dan jasa yang telah penulis terima, penulis tidak mampu membalasnya. Hanya kepada Allah SWT. penulis panjatkan doa, semoga amal kebaikannya dibalas dengan pahala yang berlipat ganda. Aamiin.

\section{DAFTAR PUSTAKA}

Arikunto, S. (2002). Prosedur Penelitian. Jakarta: PT Rineka Cipta.

Barton, B. (2016). Mathematics, education \& culture: a contemporary moral imperative. Proceedings of 13 th International Congress on Mathematical Education. Hamburg, Germany.

D'Ambrosio, U. (1985). Ethnomathematics and its place in the history and pedagogy of mathematics. For the Learning of Mathematics, 5(1), 44-48.

Sugiyono. (2017). Metode Penelitian Kebijakan: Pendekatan Kuantitatif, Kualitatif, Kombinasi, R\&D dan Penelitian Evaluasi. Bandung : Alfabeta. 
-106 Jurnal Teori dan Riset Matematika (TEOREMA) Vol. 2 No. 2, Hal, 106-106, Maret 2018

Cara sitasi: Aini, I. N. 2018. ETNOMATEMATIKA: Matematika dalam Kehidupan Petani di Kabupaten Karawang. Teorema: Teori dan Riset Matematika Vol 2, No 2 (2018). Hal 101-106 